\title{
Synthesis of Chiral Azophenolic Pyridino-18-Crown-6 Ether and Its Enantiomeric Recognition toward Chiral Primary Amines
}

\author{
Jae-kon Kim, Suhee Song, Jaehong Kim, Tae Hyun Kim, ${ }^{\dagger}$ Hasuck Kim, and Hongsuk Suh ${ }^{\star}$ \\ Department of Chemistry and Center for Plastic Information Systems, Pusan National University, Busan 609-735, Korea \\ "E-mail: hssuh(@pusan.ac.kr \\ "School of Chemisty, Seoul National University, Seonl 151-742, Korea \\ Received April 18, 2006
}

\begin{abstract}
The article reports the synthesis and enantiomeric recognition of a new chiral azophenolic pyridino-18-crown6 ether, $(S, S)-6$, possessing diphenyl groups as chiral barriers. The association constants for the enantiomeric recognition of chiral primary amines (7-12) using chiral azophenolic pyridino-18-crown-6 ether, $(S, S)$-6, were determined by UV-visible titration method in acetonitrile at $25^{\circ} \mathrm{C}$.
\end{abstract}

Key Words : Azophenolic chiral crown ether, Pyridine-18-crown-6, Chiral recognition, Enantiomeric recognition

\section{Introduction}

Host-guest chiral recognition plays an important role in biological process, resolution of enantiomers, and asymmetric catalysis reactions.' Hence, the successful design, synthesis, and use of chiral macrocyclic ligands capable of the selective recognition of the guests have attracted much attention for the investigations of catalysis, ${ }^{2,3}$ separations, 4,5 and enzyme mimics. ${ }^{\text {f- } 8}$ There are numerous amines and ammonium salts which are basic building blocks of biological molecules. Enatiomeric recognition of these molecules are of considerable significance since a number of them are known to possess potent biological activities which are different from their enantiomers. ${ }^{9}$ Out of various types of host molecules investigated, chiral crown ethers have been quite successful for the chiral discrimination of primary amine-containing compounds. Kaneda, Naemura, Hirose, and co-workers have studied the syntheses and characterization of a number of chiral crown ethers having azophenol group capable of enantiomeric recognition toward chiral amines. ${ }^{10}$ This chiral azophenolic crown ethers displayed enantioselective color changes upon complexation with guest enantiomers.

Our interest has been focused on the enantiomeric recognition of chiral amines utilizing synthetic chiral pyridine-18crown-6. We report herein the synthesis of chiral azophenolic pyridino-18-crown-6 ether $(S, S)-6$ and their enantiomeric recognition of several chiral primary amines $((R) /(S)$ alaninol $(7),(R) /(S)$-sec-butylamine $(8), \quad(R) /(S)$-phenylgylcinol $(9),(R) /(S)$-methylbenylamine $(\mathbf{1 0}),(R) /(S)$-natphylethylamine (11), and $(R) /(S)$-cyclohexylethanamine (12)). The association constants of $(S, S): 6$ - chiral amine complexes were determined by UV-visible titration in acetonitrile at 25 ${ }^{\circ} \mathrm{C}$.

\section{Experimental Section}

General. ${ }^{1} \mathrm{H}-\mathrm{NMR}$, and ${ }^{13} \mathrm{C}-\mathrm{NMR}$ spectra were recorded on a Varian Unity Plus $5(500 \mathrm{MHz})$ and Varian Gemimi 200 $(200 \mathrm{MHz})$. Melting points were determined on a ThomasHoover apparatus and are uncorrected. High-resolution mass spectra (HRMS) were recorded on a JEOL JMS-700 mass spectrometer under fast atom bombardment (FAB) conditions with Nitrobenzyl alcohol (NBA) as the matrix in the Korea Basic Science Institute (Daegu), Korea. Flash column chromatography was performed using E. Merck silica gel (60, particle size $0.040-0.063 \mathrm{~mm}$ ). Analytical thin layer chromatography (TLC) was performed using pre-coated TLC plates with silica Gel $60 \mathrm{~F}_{254}$ (E. Merck no. 5715-7). All reactions were carried out under argon atmosphere with dry solvent, unless otherwise noted. Tetrahydrofuran (THF), and diethyl ether were distilled from sodium/benzophenone immediately prior to use and methylene chloride $\left(\mathrm{CH}_{2} \mathrm{Cl}_{2}\right)$ was dried from calcium hydride.

All chemicals were reagent grade unless otherwise specified. The $(R)$ - and $(S)$-chiral amines were obtained from Aldrich Chemical Co. and used without purification. The (2S)-2-(methoxymethoxy)-2-phenylethanol (2) was prepared using our previously reported methods. "I 1,3-Bis(bromomethyl)-2,5-dimethoxybenzene was synthesized according to the literature method.'2 7-Tetraoxa-23-azatricyclo$\left[17.3 .1 .1^{8,12}\right]$ tetracosa-1(23),8(24),9,11,19,21-hexaene was synthesized using the reported analogous method. ${ }^{10}$

(5S,15S)-5,15-Diphenyl-3,6,14,17-tetraoxa-23-azatricyclo[17.3.1.1 ${ }^{8,12}$ ]tetracosa-1(23),8,11,19,21-pentaene-10,24-dione (5). To a stirred solution of $(S, S)-4(0.42 \mathrm{~g}, 0.78 \mathrm{mmol})$ in acetonitrile $(20 \mathrm{~mL})$ at $50^{\circ} \mathrm{C}$ under $\mathrm{Ar}$ was added cerium (IV) ammonium nitrate $(2.55 \mathrm{~g}, 4.65 \mathrm{mmol})$ in acetonitrile $(10 \mathrm{~mL})$. The reaction mixture was stirred at room temperature for $3 \mathrm{~h}$. After cooling to $0^{\circ} \mathrm{C}$, the reaction mixture was treated with $5 \mathrm{~mL}$ of water. The reaction mixture was extracted with chloroform $(3 \times 60 \mathrm{~mL})$ and the combined organic layer was washed with water, dried over $\mathrm{MgSO}_{4}$ and concentrated under reduced pressure. The residue was purified by flash chromatography to give $(S, S)-5(0.19 \mathrm{~g}$, $48 \%)$ as a yellow oil $\left(R_{f} 0.40, \mathrm{SiO}_{2}, 2 \% \mathrm{MeOH}-\mathrm{CH}_{2} \mathrm{Cl}_{2}\right),{ }^{1} \mathrm{H}-$ 
<smiles>COC(COCc1cccc(COCC(OC)c2ccccc2)n1)c1ccccc1</smiles>

$(S, S)-2$

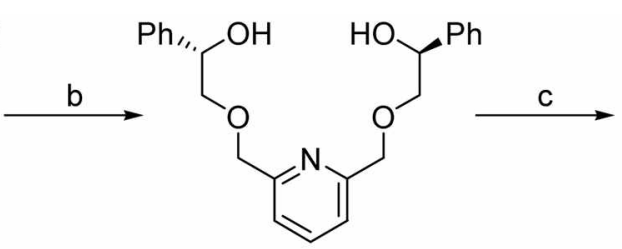

$(S, S)-\mathbf{3}$

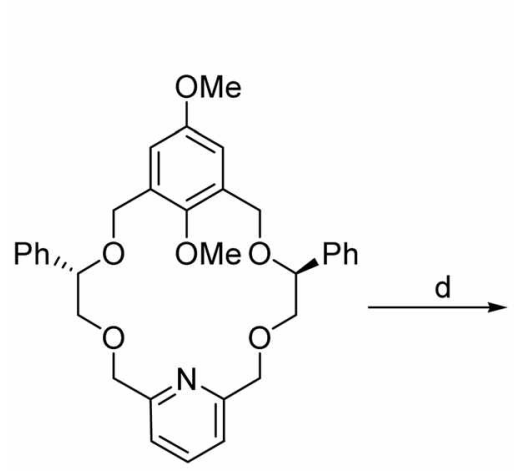

$(S, S)-4$

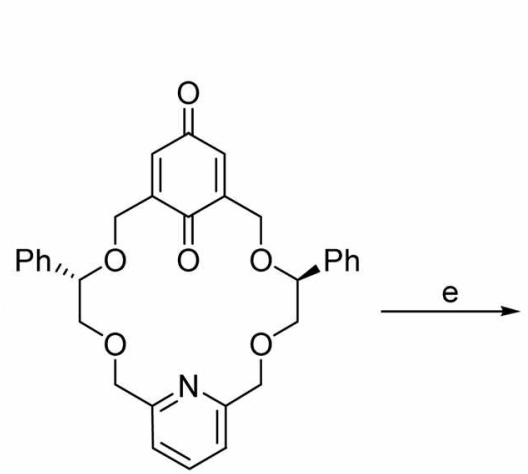

$(S, S)-5$<smiles>O=[N+]([O-])c1ccc(N=Nc2cc(COC(COCc3cccc(COCC(c4ccccc4)c4ccccc4)n3)c3ccccc3)c(O)c(COC(c3ccccc3)c3ccccc3)c2)c([N+](=O)[O-])c1</smiles>

$(S, S)-6$

Scheme 1. Reaction conditions; (a) 2,6-Bis(iodomethyl)pyridine, NaH, DMF, $90{ }^{\circ} \mathrm{C}, 24 \mathrm{~h}$ (b) 10\% HCl, THF, $50{ }^{\circ} \mathrm{C}, 5 \mathrm{~h}$; (c) $1,3-$ Bis(bromomethyl)-2,5-dincthoxybenzenc, $\mathrm{NaH}, \mathrm{THF}, 80^{\circ} \mathrm{C}$ to $50^{\circ} \mathrm{C}, 48 \mathrm{~h}$; (d) cerium(IV) aunınoniuın nitrate, $\mathrm{CH} 3 \mathrm{CN}$, room temp., $3 \mathrm{~h}$; (e) 2,4-dinitrophenylhydrazine, $\mathrm{CH}_{2} \mathrm{Cl}_{2}$, ethanol, room temp., $3 \mathrm{~h}$.

$\operatorname{NMR}\left(200 \mathrm{MHz}, \mathrm{CDCl}_{3}\right) \delta 3.73-3.79(\mathrm{~m}, 4 \mathrm{H}), 3.93(\mathrm{~d}, 2 \mathrm{H}, J$ $=11 \mathrm{~Hz}), 4.41(\mathrm{~d}, 2 \mathrm{H}, J=11 \mathrm{~Hz}), 4.50-4.70(\mathrm{~m}, 8 \mathrm{H}), 6.67(\mathrm{~s}$, $2 \mathrm{H}), 7.11-7.48(\mathrm{~m}, 12 \mathrm{H}), 7.72(\mathrm{t}, 1 \mathrm{H}, J=6.6 \mathrm{~Hz}) ;{ }^{13} \mathrm{C}-\mathrm{NMR}$ $\left(50 \mathrm{MHz}, \mathrm{CDCl}_{3}\right) \delta 64.8,73.9,75.7,80.1,120.6,126.5$, $128.1,128.6,132.6,137.0,138.0,144.6,157.7,185.7$, 187.5; HRMS (FAB, NBA) calcd 512.2073 for $\mathrm{C}_{31} \mathrm{H}_{30} \mathrm{NO}_{6}$ $(\mathrm{M}+\mathrm{H})^{+}$, found 512.2073 .

$(5 S, 15 S)-10-[(E)$-(2,4-Dinitrophenyl)diazenyl]-5,15-diphenyl-3,6,14,17-tetraoxa-23-azatricyclo[17.3.1.1 ${ }^{8.12}$ ]tetracosi-1(23),8(24),9,11,19,21-hexaen-24-ol (6). To a stirred solution of $(S, S)-5(0.18 \mathrm{~g}, 0.35 \mathrm{mmol})$ in methylene chloride $(5 \mathrm{~mL})$ and ethanol $(5 \mathrm{~mL})$ at room temperature under $\mathrm{Ar}$ was added 2,4-dinitrophenylhydrazine hydrogen chloride $(0.41 \mathrm{~g}, 1.76 \mathrm{mmol})$ in ethanol $(10 \mathrm{~mL})$. After stirring at room temperature for $3 \mathrm{~h}$, the reaction mixture was treated with $5 \mathrm{~mL}$ of water and extracted with chloroform $(3 \times 40 \mathrm{~mL})$. The combined organic layer was washed with saturated aqueous $\mathrm{NaHCO}_{3}$ and water, dried over $\mathrm{MgSO}_{4}$ and concentrated under reduced pressure. The residue was purified by flash chromatography to give $(S, S)-6$ $(0.16 \mathrm{~g}, 66 \%)$ as a red solid $\left(R_{f} 0.30, \mathrm{SiO}_{2}, 3 \% \mathrm{MeOH}-\right.$ $\left.\mathrm{CH}_{2} \mathrm{Cl}_{2}\right) ;[\alpha]_{\mathrm{D}}^{24}=+58.5^{\circ}\left(\mathrm{c}=0.1, \mathrm{CHCl}_{3}\right) ; \mathrm{mp}: 87-88^{\circ} \mathrm{C}$; 'H-NMR $\left(500 \mathrm{MHz}, \mathrm{CDCl}_{3}\right) \delta 3.73(\mathrm{dd}, 2 \mathrm{H}, J=2.5,9.1$ $\mathrm{Hz}), 3.88(\mathrm{dd}, 2 \mathrm{H}, J=2.5,9.1 \mathrm{~Hz}), 4.50(\mathrm{~s}, 4 \mathrm{H}), 4.78(\mathrm{~m}$, $6 \mathrm{H}), 7.32-7.39(\mathrm{~m}, 12 \mathrm{H}), 7.68(\mathrm{~s}, 2 \mathrm{H}), 7.79(\mathrm{~d}, 1 \mathrm{H}, J=2.4$ $\mathrm{Hz}), 8.49$ (dd, $1 \mathrm{H}, J=2.4,8.8 \mathrm{~Hz}), 8.75(\mathrm{~d}, 1 \mathrm{H}, J=2.4 \mathrm{~Hz}$ ), $9.18(\mathrm{~s}, 1 \mathrm{H}) ;{ }^{13} \mathrm{C}-\mathrm{NMR}\left(125 \mathrm{MHz}, \mathrm{CDCl}_{3}\right) \delta 68.3,73.2$, $75.0,81.4,119.9,120.0,121.6,125.5,126.8,126.9,127.5$, $128.4,128.7,130.7,137.8,145.8,146.8,148.9,157.1$, 161.0; HRMS (FAB, NBA) calcd 692.2356 for $\mathrm{C}_{31} \mathrm{H}_{30} \mathrm{NO}_{6}$ $(\mathrm{M}+\mathrm{H})^{+}$, found 692.2355 .

\section{Results and Discussion}

Synthesis and Characterization. Chiral azophenolic pyridino-18-crown-6 ether $(S, S)$-6 with diphenyl group as chiral barriers were synthesized for the enantiomeric recognition of chiral primary amines. The synthesis of the designed chiral azophenolic pyridino-18-crown-6 ether $(S, S)$-6 is summarized in Scheme 1. The chiral subunit alcohol $(S)-1$ was prepared from $(S)-(+)$-mandelic acid using our previously reported route. ${ }^{11}$ The alcohol $(S)-1$ was coupled with the 2,6-bis(jodomethyl)pyridine by using sodium hydride to generate $(S, S)-2$ in $51 \%$ yield. The MOM-protecting group of $(S, S)-2$ was removed by using $10 \% \mathrm{HCl}$ to afford the diol $(S, S)-3$, the southern part of the macrocycle, in $81 \%$ yield. The generated compound $(S, S)-3$ was coupled with the 1,3bis(bromomethyl)-2,5-dimethoxybenzene, ${ }^{12}$ the northem part of the macrocycle, by using sodium hydride in THF under high dilution conditions to afford the macrocycle $(S, S)-4$ in $42 \%$ yield. The oxidation ${ }^{13}$ of $(S, S)-4$ with cerium(IV) ammonium nitrate in acetonitrile generated $(S, S)-5$ in $48 \%$ yield, which was immediately treated with 2,4-dinitrophenylhydrazine in methylene chloride and ethanol to obtain chiral azophenolic pyridino-18-crown- 6 ether $(S, S)-6$ as a red solid in $66 \%$ yield.

UV-visible Titration Studies. The chiral azophenolic crown ether $(S, S)-6$ is a red indicator that can generate a new blue anionic ligand $(S, S)-6^{-}$by deprotonation. To investigate the enantiomeric recognition, chiral azophenolic crown ether $(S, S)-6$ was treated with chiral primary amines $((R) /(S)$ alaninol $(7),(R) /(S)$-sec-butylamine $(8),(R) /(S)$-phenylgylcinol (9), $(R) /(S)$-methylbenylamine (10), $(R) /(S)$-natphyl- 
<smiles>CC(N)CO</smiles>

7<smiles>CCC(N)c1ccccc1</smiles>

10<smiles>CCC(C)N</smiles>

8<smiles>CC(N)c1cccc2ccccc12</smiles>

11<smiles>NC(CO)c1ccccc1</smiles>

9

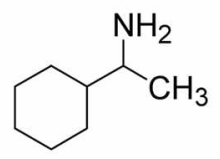

12
Figure 1. The chemical structure of chiral primary amines (7-12) used in experiments.

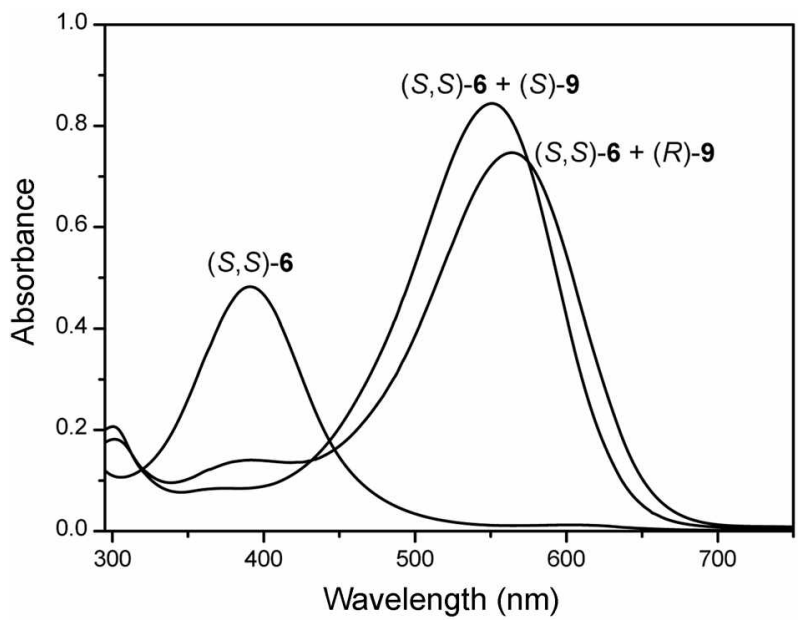

Figure 2. UV-visible spectra changes of chiral azophenolic crown cther $(S, S)-6(0.02 \mathrm{mM})$ in the presence of $(R)$, and $(S)$ phenylglycinol $(9)(4.0 \mathrm{mM})$ in acetonitrile at $25^{\circ} \mathrm{C}$.

ethylamine (11), and $(R) /(S)$-cyclohexylethanamine (12)) as shown in Figure 1.

The titration experiments for the complexation of the host $(S, S)-6$ with chiral amine $(R)-8$ are described here as an example for the determination of the association constants by UV-visible spectroscopy. A solution of $(S, S)-6$ in acetonitrile was prepared and an initial UV spectrum of this solution was recorded. Separately, a solution of $(R)-8$ in acetonitrile was prepared. Samples were made by adding the guest solution to the host solution and dilution with acetonitrile to make the total volume of $4.0 \mathrm{~mL}$, so that the concentration of the guest in each samples were $0.0,2.0,4.0$, $8.0,14$, and $20 \mathrm{mM}$, respectively. The concentration of the host was kept constant at $0.02 \mathrm{mM}$ in each sample. Then, the spectra of these twelve different solutions were recorded. The binding constants were calculated from the absorption intensity of the complexes at absorption maximum based on the Rose-Drago method. ${ }^{1+}$ The spectrophotometric behavior of $(S, S)-6$ with colorless chiral amines such as 7-12 was examined in acetonitrile at $25^{\circ} \mathrm{C}$. $(S, S)-6$ itself has absorption maxima at $397 \mathrm{~nm}$. As the chiral amine was added to $(S, S)-6$, the new absorption band was developed at long wavelength and its absorbance was increased in proportion
Table 1. Association constants $\left(K_{\mathrm{a}} / \mathrm{mol}\right)$ of chiral azophenolic crown ether $(S, S)-6$ with chiral primary amines (7-12) in acetonitrile at $25^{\circ} \mathrm{C}$

\begin{tabular}{|c|c|c|c|}
\hline Entry & Amine & $K_{a}$ & $\alpha\left[K_{\mathrm{a}}(R) / K_{\mathrm{a}}(S)^{\prime}\right.$ \\
\hline 1 & $\langle(R)-7$ & $12.6( \pm 0.7) \times 10^{3}$ & 1.07 \\
\hline 2 & (5) 7 & $11.7( \pm 0.7) \times 10^{3}$ & \\
\hline 3 & $(R)-8$ & $104( \pm 0.7)=10^{3}$ & 1.55 \\
\hline 4 & $(S)-8$ & $67.4( \pm 0.7) \times 10^{3}$ & \\
\hline 5 & $(R)-9$ & $8.19( \pm 0.7) \cdot 10^{3}$ & 1.16 \\
\hline 6 & $(S\})-9$ & $7.05( \pm 0.7)-10^{2}$ & \\
\hline 7 & $(R)-10$ & $11.3( \pm 0.7) \times 10^{3}$ & 0.85 \\
\hline 8 & $(S)-10$ & $13.3( \pm 0.7)<10^{3}$ & \\
\hline 9 & $(R\}-11$ & $6.72( \pm 0.7)-10^{3}$ & 0.85 \\
\hline 10 & $(S)-11$ & $7.94( \pm 0.7) \times 10^{3}$ & \\
\hline 11 & $(R)-12$ & $93.8( \pm 0.7) \times 10^{3}$ & 1.06 \\
\hline 12 & $(S)-12$ & $87.9( \pm 0.7)-10^{2}$ & \\
\hline
\end{tabular}

${ }^{\alpha} K_{s}(R)$ for the complex with $(R)$-amine and $K_{3}(S)$ for the complex with (S)-amine.

to the concentration of chiral amine. The observed absorption maxima of the complexes in acetonitrile appeared in the wavelength region of $563-590 \mathrm{~nm}$. For example, as shown in the Figure 2, when $(R)-9$ and $(S)-9$ were added to $(S, S)-6$, a new absorption maxima for the $(S, S)-6:(R)-9$ complex and $(S, S)-6:(S)-9$ complex were observed at $568 \mathrm{~nm}$ and $563 \mathrm{~nm}$, respectively.

The association constants $\left(K_{2}\right)$ for $(S, S)-6$ with chiral amines 7-12 were determined by the Rose-Drago method ${ }^{14}$ on the basis of the UV-visible titration of complexes in acetonitrile at $25^{\circ} \mathrm{C}$. The chiral amines causing higher association constants gave rise to lager blue-shift, although the $(S, S)-6$ : chiral amine 7-12 system does not exhibit a clear proportional relationship. The association constants and the ratio of association constants $K_{2}(R) / K_{2}(S)$ are summarized in Table 1. Among them, the association constants of $(S, S)-6$ with the $(R) /(S)$-enantiomer of secbutylamine (8) were found to be $104( \pm 0.7) \times 10^{3} \mathrm{M}^{-1}$ and $67.4( \pm 0.7) \times 10^{3} \mathrm{M}^{-1}$, respectively. The ratio of association constants $K_{a}(R) / K_{\mathrm{a}}(S)$ of sec-butylamine was 1.55 . The chiral macrocyle $(S, S)-6$ exhibits good recognition for 8 , and show a little for 9,10 , and 11, but no enantiomeric recognition for 7, and 12. Even though it is quite difficult to extract any clear reason of this trend, the hydrogen bonding of the ammonium salt of the guest with the oxygens and nitrogen of the macrocyle, and the steric effects of the diphenyl group of the macrocyle could play important roles in enantiomeric recognition. Out of the factors mentioned above, the hydrogen bonding between the host and the guests may lead to the formation of the complex, while steric interaction contributes to enantiomeric recognition.

\section{Conclusion}

In conclusion, the synthesis and enantiomeric recognition of a new chiral azophenolic pyridino-18-crown- 6 ether $(S, S)-6$ possessing diphenyl groups as chiral barriers are reported. The association constants for the enantiomeric 
recognition of chiral primary amines (7-12) using chiral azophenolic pyridino-18-crown-6 ether, $(S, S)-6$, were determined by UV-visible titration method in acetonitrile at 25 ${ }^{\circ} \mathrm{C}$. The chiral macrocyle $(S, S)-6$ exhibits good recognition for 8 , and show a little for 9,10 , and 11 , but no enantiomeric recognition for 7 , and 12 .

Acknowledgment. This work was supported by the Ministry of Information \& Communications, Korea, under the Information Technology Research Center (ITRC) Support Program.

Supporting Information: The spectroscopic data and experimental procedures for the syntheses of compound 2-4 are available $v$ ia the intemet at http: $/ / w w w . k c s n e t . o r . k r / b k c s$.

\section{References and Notes}

1. Izath, R. M.; Wann, T.; Hathaway, J. K.; Zhang, X. X.; Curtis, J. C.; Bradshaw, J. S.; Zhu, C. Y. J. Incl. Phenom, 1994, 17, 157.

2. Grove, J. T.; Viski, P. J. Ong. Chem. 1990, 55, 3628.

3. O'Malley, S.; Kodadek, T. Organometallics 1992, 11, 2299.

4. (a) Gasparrini, F.; Misiti, D.; Borchardt, A.; Burger, M. T.; Still, W. C. J. Org. Chem. 1995, 60, 4314, (b) Helgeson, R. C.; Koga, K.; Timko. J. M.; Cram, D. J. J. An. Chen. Soc. 1973, 95,3021 .

5. (a) Ryoo, J. J.; Song, Y.-A.; Jeong, Y. H.; Hyun, M. H.; Park, J. H.; Lee, W. Bull. Korean Chem. Soc. 2006, 27, 637, (b) Ryoo, J. J.; Song, Y.-A.; Lee, K.-P.; Park, J. Y.; Choi, S.-H.; Hyun, M. H.; Ohta, K.; Fujimoto, C.; Jin, J.-Y.; Takeuchi, T.; Lee, J. W. Bull. Korean Chent. Soc. 2006, 27, 524, (c) Kim, I. W.; Kwon, S. H.; McNeff, C. V.; Carr, P. W.; Jang, M. D.; Park, J. H. Bull. Koreun
Chem. Soc, 2006, 27, 589.

6. Chao, Y.; Cram, D. J. J. Am. Chent Soc. 1976, 98, 1015.

7. Breslow, R.; Czarnik, A. W.; Lauer, M.; Leppkes, R.; Winkler, J.; Zimmerman, S. J. Am. Chent. Soc. 1986, 108, 1969.

8. Talma, A. G; Jouin, P.; De Vries, J. G; Troostwijk, C. B.; Werumeus Buning, Gi H.; Waninge, J. K.; Visscher, J.; Kellogg, R. M. J. Am. Chem. Soc. 1985, 107, 3981 .

9. Zhang, X. X.; Bradshaw, J. S.; Izatt, R. M. Chem. Rev. 1997, 97, 3313 .

10. (a) Kaneda, T.; Ishizaki, Y.; Misumi, S.; Kai, Y.; Hirao, G.; Kasai, N. J. Am. Chem. Soc, 1988, 110, 2970. (b) Kaneda, T.; Hirose, K,; Misumi, S. J. Am. Chem. Soc. 1989, H1, 742, (c) Kaneda, T.; Umeda, S.; Ishizaki, Y.; Kuo, H.-S.; Misumi, S.; Kai, Y.; Kanehisa, N.; Kasai, N. J. Am. Chem. Soc. 1989, HI, 1881. (d) Naemura, K.; Ueno, K.; Takeuchi, S.; Tobe, Y.; Kaneda, T.; Sakata, Y. $J$. An. Chem. Soc. 1993, 115, 8475. (e) Naemura, K.; Takeuchi, S.; Asada, M.; Hirose, K.; Tobe, Y.; Kaneda, T.; Sakata, Y. J. Chem. Soc. Chem. Commm. 1994, 711 . (I) Naemura, K.; Takeuchi, S.; Hirose, K.; Tobe, Y; Kaneda, T.; Sakata, Y. J. Chem. Soc., Perkin. Trans. 1 1995, 213. (g) Naemura, K.; Ueno, K.; Takeuchi, S.; Hirose, K.; Tobe, Y.; Kaneda, T.; Sakata, Y. J. Chem. Soc., Perkin Trans. 1 1996, 383. (h) Naemura, K.; Ogasahara, K.; Hirose, K.; Tobe, Y. Tetrahedron: Asymmetry 1997, \&, 19. (i) Hirose, K.; Fujiwara, A.; Matsunaga, K.; Aoki, N.; Tobe, Y. Tetrahedron 2002, 43, 8539. (j) Hirose, K.; Fujiwara, A.; Matsunaga, K.; Aoki, N.; Tobe, Y. Tetrahedron Asymmetry 2003, 14, 555.

I1. Suh, H.; Kim, J.-K.; Jung, I. S.; Lee, S. E.; Kang, S. W.; Park, J. S. Bull. Korean Chem. Soc. 1998, 19, $41 \mathrm{l}$.

12. Moran, W. J.; Schreiber, E. C.; Engel, E.; Behn, D. C.; Yamins, J. L. J. Am. Chem. Soc. 1954, 74, 127.

13. Jacob, P.; Callery, P. S.; Shulgin, A. T.; Castagnoli, N. J. Org. Chent. 1976, 41, 3627 .

14. (a) Rose, N. J.; Drago, R. S. J. An. Chem. Soc. 1959, 81, 6138. (b) Hirose. K. J. Ind. Phenom. 2001, 39, 193. 